\title{
Mediterranean Fever Gene Mutations and Messenger Ribonucleic Acid Expressions in Pediatric Patients With Familial Mediterranean Fever in the Trakya Region of Turkey
}

\author{
Hilmi TOZKIR, ${ }^{1}$ Hakan GÜRKAN, ${ }^{1}$ Neşe ÖZKAYIN, ${ }^{2}$ Necdet SÜT ${ }^{3}$ \\ ${ }^{1}$ Department of Medical Genetics, Medical Faculty of Trakya University, Edirne, Turkey \\ ${ }^{2}$ Department of Pediatric Nephrology, Medical Faculty of Trakya University, Edirne, Turkey \\ ${ }^{3}$ Department of Biostatistics, Medical Faculty of Trakya University, Edirne, Turkey
}

\begin{abstract}
Objectives: This study aims to investigate the possible relationship between Mediterranean fever (MEFV) gene mutations and messenger ribonucleic acid (mRNA) expressions and to identify the link between phenotype and genotype of pediatric patients with Familial Mediterranean fever (FMF).

Patients and methods: Seventy-one pediatric FMF patients who were identified with FMF symptoms and diagnosed with FMF according to Tel Hashomer criteria were included at Trakya University, Faculty of Medicine, Department of Paediatric Nephrology. The control group consisted of 73 healthy pediatric participants. Genomic deoxyribonucleic acid was isolated from whole blood samples and the following mutations of MFEV gene were analyzed: E148Q, P369S, H478Y, H479L, S675N, G678E, M680L, M680I (G>A and G>C), T681I, I692del, M694V, M694L, M694I, M695R, M695M, R717S, I720M, V722M, V726A, A744S and R761H. Total RNA isolation from leukocytes was performed and MEFV mRNA expression levels of the patients were compared by using real-time quantitative polymerase chain reaction method. $\beta 2$ microglobulin was selected as the control gene. The comparison of mRNA expression levels among the patients was performed using the $\triangle C T$ method.

Results: The most common clinical findings were abdominal pain, fever and vomiting. The mutation detection rate in the patient group was $\mathrm{OR}=4.1(95 \% \mathrm{Cl}: 1.8-9.0)$ times higher than that of the control group. The MEFV mRNA expression level of the patients with MEFV gene mutations was lower compared to the control group, indicating statistical significance.

Conclusion: Our study results support the findings of previous studies indicating that the MEFV mRNA expression levels of pediatric FMF patients with MEFV gene mutation are lower than the MEFV mRNA expression levels of healthy controls.

Key words: Familial Mediterranean fever; inflammation; messenger ribonucleic acid; mutation.
\end{abstract}

Familial Mediterranean fever (FMF, OMIM $\neq 249100$ ) is an autosomal recessive inherited autoinflammatory disease that commonly affects people of East Mediterranean ethnic origin; primarily those of Turkish, Greek, Druze, Arab, Armenian and non-Ashkenazi Sephardi (Sephardic) Jewish descent. ${ }^{1-6}$ Familial Mediterranean fever has also been reported with incomplete penetrance in other Mediterranean countries, such as Cyprus, Italy, Spain and Greece. ${ }^{7}$ The disease is characterized by recurrent and self-limiting episodes of fever, serosal inflammation of the membranes (the synovial membrane, the peritoneum and pleura), abdominal pain attacks, arthritis, skin rashes and serum amyloid A protein deposition in kidneys unless treatment is provided. ${ }^{1-6}$ The prevalence and the carrier rate of FMF in Turkey have been reported as $1 / 1,000$ and $20 \%$, respectively. ${ }^{8,9}$

Mutations in the Mediterranean fever (MEFV) gene, which is mapped to chromosome $16 \mathrm{p} 13.31-5$, play an important role in the pathogenesis of FMF. ${ }^{1-5}$ The MEFV gene codes for a 781 amino acid (aa) marenostrin/pyrin

Received: April 25, 2013 Accepted: September 14, 2013

Correspondence: Hakan Gürkan, M.D. Trakya Üniversitesi Tıp Fakültesi Tıbbi Genetik Anabilim Dalı, 22030 Edirne, Turkey.

Tel: +90 284 - 2357642 / 2330 e-mail: dr_hakangurkan@yahoo.de

Presented at the $10^{\text {th }}$ National Congress of Medical Genetics, December 19-23, 2012, Bursa, Turkey

(2014 Turkish League Against Rheumatism. All rights reserved. 
protein, which is expressed in neutrophils, eosinophils, cytokine activated monocytes, dendritic cells, synovial, peritoneal and skinoriginated fibroblasts. ${ }^{1-3,5}$ Marenostrin/pyrin proteins have been reported to play regulatory roles in interleukin-1 beta (IL-1 $\beta$ ) maturation, caspase-1 activation (which is responsible for $\mathrm{NF}-\kappa \mathrm{B}$ activation), apoptotic mechanisms and the regulation of innate immunity leading to both proinflammatory and anti-inflammatory effects., ${ }^{2,3,5}$ Using the green fluorescent protein fusion assay method, it was shown that the full-length (781 aa) marenostrin/pyrin protein is located in cytoplasmic perinuclear region and is associated with microtubules and actin filaments via a B30.2 domain., ${ }^{1,2}$ A shorter form of marenostrin/ pyrin is located inside the nucleus. This 570 aa form is translated from the second exon via alternative splicing and lacks the MEFV-d2 transcripts. It has been reported that the MEFV gene is regulated by nonsense-mediated decay, and different isoforms of the MEFV transcript are located at different cellular regions, with different roles in the inflammation process. ${ }^{2}$

To date, 227 FMF-associated polymorphisms/ mutations (221 substitutions, 2 insertions, 2 deletions and 2 duplications) of the marenostrin/ pyrin coding MEFV gene have been reported. These MEFV polymorphisms/mutations are located in the following regions of the coding gene: exon $10(70)>$ exon $2(64)>$ exon $5(22)>$ exon $3(21)$ > exon 1 (5). ${ }^{10}$ According to the results of studies investigating the relationship between MEFV mutations and messenger RNA (mRNA) expression, increasing numbers of MEFV gene mutations are correlated with decreased mRNA expression level. The mRNA expression levels of peripheral blood leukocyte (PBLs) samples from FMF patients have been reported to be lower than those of healthy controls. ${ }^{2,3}$

In this study, we investigated the relationship between mRNA expression levels and MEFV gene mutations in pediatric patients whose clinical diagnosis of FMF were decisive according to the Tel-Hashomer criteria. We aimed to elucidate the relationship between FMF phenotype and genotype. Furthermore, this is the second study investigating the relationship between mRNA expression levels and MEFV mutations in Turkish pediatric patients.

\section{PATIENTS AND METHODS}

Between January 2010 and June 2012, 71 pediatric FMF patients (average age $10.68 \pm 4.4$ years) were identified from the Trakya University Faculty of Medicine, Department of Pediatric Nephrology with FMF symptoms and diagnosed as FMF according to the Tel-Hashomer criteria. The healthy control group contained 73 pediatric patients (average age $9.12 \pm 4.9$ years) who did not have abdominal pain, fever attacks and any kidney disease. The patients and controls were not related. Local Ethics Committee approval was given by the Trakya University Faculty of Medicine Clinical Research Ethics Committee of Non-Interventional Study Protocol on 07.08.2008 with a 16/20 decision, following inspection of the study protocol and the informed consent form. The informed consent form includes information about the study, and this form was read and signed by the parents of all pediatric patients and all pediatric control subjects.

Genomic deoxyribonucleic acid (gDNA) was isolated from whole blood samples using an EZ1 DNA Isolation Kit $\left(E Z 1{ }^{\circledR}\right.$ DNA Blood $200 \mu$ Kit, Qiagen, Hilden, Germany) with automated EZ1 Advanced XL (Qiagen, Hilden, Germany). The $200 \mu$ whole blood sample was used for DNA isolation and final dilution was $100 \mu \mathrm{l}(\sim 40-50 \mathrm{ng} /$ $\mu$ DNA). Mutation analysis was performed using Pyro Sequencing FMF Primers kit (ATQ Biotech, Ankara, Turkey) with PYRO Sequencing (Qiagen, Hilden, Germany). Exons 2, 3, 5 and 10 were analyzed using this FMF kit, and codons that were examined for mutations included the following: E148Q in exon 2; P369S in exon 3; H478Y, $\mathrm{H} 479 \mathrm{~L}$ in exon 5; S675N, G678E, M680L, M680I (G>A and G>C), T681I, I692del, M694V, M694L, M694I, M695R, M695M, R717S, I720M, V722M, V726A, A744S and R761H in exon 10. Each sample was studied twice to increase the reliability of the study.

Total RNA isolation from whole leukocytes was performed using a QIAamp ${ }^{\circledR}$ RNA Blood Mini Kit (Qiagen, Hilden, Germany). Ribonucleic acid isolation was performed using a $1.5 \mathrm{ml}$ whole blood sample and erythrocytes were lysed via elution buffer provided by a supplier. Leucocytes were recovered selectively by centrifugation according to the supplier's procedure. RNA was isolated from recovered leucocytes. 
For each sample, the RNA concentration was measured with a Nanodrop 2000c Spectrophotometer (Thermo Scientific, Wilmington, USA) and diluted to $1000 \mathrm{ng} / \mu \mathrm{l}$ to get more significant quantitative results. To prevent gDNA contamination, isolated RNA samples were treated with a gDNA wipeout solution, and complementary DNA was synthesized immediately using a QuantiTect Reverse Transcription cDNA kit, according to the manufacturer's handbook instructions (Qiagen, Hilden, Germany). The cDNA concentration was also diluted to $1000 \mathrm{ng} / \mu \mathrm{l}$.

Quantitative expression analysis was performed with a quantitative polymerase chain reaction (Q-PCR) method using the Corbett RG-6000 real-time (quantitative) PCR machine (Qiagen, Hilden, Germany). The Q-PCR method was applied using a QuantiFast SYBR Green PCR Kit (Qiagen, Hilden, Germany). $\beta_{2}$ microglobulin (B2M) was selected as the control gene, and thus, two reaction tubes were studied for each patient; one reaction was for the MEFV gene, and the other one was for B2M. Each reaction tube contained $12.5 \mu$ of SYBR Green, $2.5 \mu \mathrm{l}$ of forward primer for either the B2M or MEFV gene, $2.5 \mu$ l of reverse primer for either the $\mathrm{B} 2 \mathrm{M}$ or MEFV gene and $5 \mu \mathrm{l}$ of cDNA, which was diluted to $1000 \mathrm{ng} / \mu \mathrm{l}$. The following primers were designed for the $\mathrm{B} 2 \mathrm{M}$ gene: forward primer: 5'TGC-CGT-GTG-AAC-CATGTG-AC-3'; and reverse primer: 5'-ACC-TCCATG-ATG-CTG-CTT-ACA-3'. The following primers were designed for exons 2 and 3 of the MEFV gene: forward primer: 5'-GGAAAA-GAC-AGC-TGC-GAA-TC-3'; and reverse primer: 5'-TCA-ACT-GGG-TCT-CCT-TCC-TG-3'. For each sample, both MEFV gene expression analysis and $\mathrm{B} 2 \mathrm{M}$ gene expression analysis were studied twice.

The relative expression level was calculated using the $\Delta \mathrm{CT}$ method $(\Delta \mathrm{CT}=\mathrm{CT}$ of $\mathrm{B} 2 \mathrm{M}-\mathrm{CT}$ of $\mathrm{MEV}$, and the 2- $\Delta \mathrm{CT}$ value corresponds to the fold change between target gene, MEFV, and the reference gene, $\mathrm{B} 2 \mathrm{M}$ ).

\section{Statistical analysis}

In this study, the suitability of the quantitative values for a normal distribution was analyzed with a single sampling Kolmogorov-Smirnov test. Normally distributed age values were analyzed with the Student's t-test, while non-normally distributed expression level values were analyzed using a Mann-Whitney U-test. A Chi-square test was used to analyze the categorical data of patients and controls, odds ratios and 95\% confidence intervals (CI) were then calculated. $\mathrm{P}<0.05$ was accepted as a significant statistical value. Statistical analysis was performed using the IBM SPSS Statistics 20.0 software program (IBM Corporation, Armonk, NY, USA).

\section{RESULTS}

We compared MEFV allele frequencies between FMF patients and the healthy controls, and found that 38 of the 71 patients $(53.5 \%)$ had MEFV gene mutations, whereas 33 patients (46.5\%) had no mutations. Although 16 controls (21.9\%) carried MEFV gene mutations, no mutations were detected in the other 57 healthy controls $(78.1 \%)(p<0.001)$. The mutation detection rate in the patient group was $\mathrm{OR}=4.1$ (95\% CI: 1.8-9.0) times greater than that of the control group. The distribution of MEFV gene mutations detected in the patients and controls and the localizations of the mutations are shown in Table 1. The most frequent mutations detected in patients were E148Q heterozygous mutation $(n=8)$ and M694V heterozygous mutation $(\mathrm{n}=8)$. The most frequent mutation detected in the control group was E148Q heterozygous mutation $(n=7)$. Different from the patients, two controls were detected with a G678E heterozygous mutation and a single control was detected with an A744S heterozygous mutation in exon 10. Mutations in exon 5 were not detected neither in patients nor in controls. In healthy controls, the detected MEFV gene mutations affected only one allele (heterozygous), and these patients are carriers of MEFV gene mutations.

The MEFV mRNA expression level of the patients with MEFV gene mutations $(n=38)$ was lower than that of the controls $(n=73)$, these results are statistically significant [mean $\pm \mathrm{SD}$ $0.007645 \pm 0.01929$ (median 0.00300) vs. mean \pm SD $0.00579 \pm 0.01388$ (median 0.00200); $\mathrm{p}=0.009]$. Furthermore, the MEFV mRNA expression level of the patients with MEFV gene mutations $(n=38)$ was also lower than that of controls with no mutations $(n=57)$, and these results are also statistically significant [mean $\pm \mathrm{SD}$ 


\begin{tabular}{|c|c|c|c|c|c|c|}
\hline \multirow[t]{2}{*}{$\begin{array}{l}\text { Detected mutations and the } \\
\text { localization of the mutations }\end{array}$} & \multirow[t]{2}{*}{$\begin{array}{l}\text { SNP numbers of the } \\
\text { mutations detected }\end{array}$} & \multirow[t]{2}{*}{ Type of mutations } & \multicolumn{2}{|c|}{$\begin{array}{l}\text { Patients } \\
(\mathrm{n}=71)\end{array}$} & \multicolumn{2}{|c|}{$\begin{array}{c}\text { Controls } \\
(\mathrm{n}=73)\end{array}$} \\
\hline & & & $\mathrm{n}$ & $\%$ & $\mathrm{n}$ & $\%$ \\
\hline \multicolumn{7}{|l|}{ Exon 2} \\
\hline E148Q Heterozygous mutant & rs3743930 & Missense & 8 & 11.3 & 7 & 9.6 \\
\hline E148Q Homozygous mutant & rs3743930 & Missense & 2 & 3 & - & - \\
\hline \multicolumn{7}{|l|}{ Exon 3} \\
\hline P369S Heterozygous mutant & rs11466023 & Missense & 1 & 1.4 & 1 & 1.4 \\
\hline \multicolumn{7}{|l|}{ Exon 10} \\
\hline M680I (G/C) Heterozygous mutant & rs28940580 & Missense & 3 & 4.2 & - & - \\
\hline M694V Homozygous mutant & rs61752717 & Missense & 3 & 4.2 & - & - \\
\hline M694V Heterozygous mutant & rs61752717 & Missense & 8 & 11.3 & - & - \\
\hline K695R Heterozygous mutant & rs104895094 & Missense & 1 & 1.4 & 2 & 2.7 \\
\hline V726A Heterozygous mutant & rs 28940579 & Missense & 3 & 4.2 & 1 & 1.4 \\
\hline R761H Heterozygous mutant & rs104895097 & Missense & 1 & 1.4 & 2 & 2.7 \\
\hline $\begin{array}{l}\text { M680I (G/C) Heterozygous mutant (+) } \\
\text { M694V Heterozygous mutant }\end{array}$ & $\begin{array}{l}\text { rs28940580 } \\
\text { rs61752717 }\end{array}$ & $\begin{array}{l}\text { Missense } \\
\text { Missense }\end{array}$ & 3 & 4.2 & - & - \\
\hline $\begin{array}{l}\text { M694V Heterozygous mutant }(+) \\
\text { V726A Heterozygous mutant }\end{array}$ & $\begin{array}{l}\text { rs } 61752717 \\
\text { rs } 28940579\end{array}$ & $\begin{array}{l}\text { Missense } \\
\text { Missense }\end{array}$ & 2 & 3 & - & - \\
\hline $\begin{array}{l}\text { M694V Heterozygous mutant (+) } \\
\text { A744S Heterozygous mutant }\end{array}$ & $\begin{array}{l}\text { rs61752717 } \\
\text { rs61732874 }\end{array}$ & $\begin{array}{l}\text { Missense } \\
\text { Missense }\end{array}$ & 1 & 1.4 & - & - \\
\hline G678E Heterozygous mutant & rs104895088 & Missense & - & - & 2 & 2.7 \\
\hline A744S Heterozygous mutant & rs61732874 & Missense & - & - & 1 & 1.4 \\
\hline $\begin{array}{l}\text { P369S Heterozygous mutant (+) } \\
\text { K695R Heterozygous mutant }\end{array}$ & $\begin{array}{l}\text { rs11466023 } \\
\text { rs104895094 }\end{array}$ & $\begin{array}{l}\text { Missense } \\
\text { Missense }\end{array}$ & 1 & 1.4 & - & - \\
\hline $\begin{array}{l}\text { E148Q Heterozygous mutant (+) } \\
\text { M694V Heterozygous mutant }\end{array}$ & $\begin{array}{l}\text { rs3743930 } \\
\text { rs61752717 }\end{array}$ & $\begin{array}{l}\text { Missense } \\
\text { Missense }\end{array}$ & 1 & 1.4 & - & - \\
\hline
\end{tabular}

$0.00765 \pm 0.01929$ (median 0.00300) vs. mean \pm SD $0.00624 \pm 0.01541$ (median 0.00190); $\mathrm{p}=0.007]$. In the statistical analysis of comparison between patients with no MEFV gene mutations $(\mathrm{n}=33)$ and controls with no MEFV gene mutations $(\mathrm{n}=57)$, the MEFV mRNA expression levels were not found to be significantly different $(p=0.924)$.

We compared the MEFV mRNA expression levels between controls heterozygous for MEFV mutations (16 controls, all carriers) and controls without detected mutations $(n=57)$, and found no statistically significant difference $(p=0.554)$.

When we compared patients without MEFV mutations $(\mathrm{n}=33)$ to the patients with MEFV mutations $(n=38)$, the MEFV mRNA expression level differences were statistically significant, but the values were borderline [mean \pm SD $0.007645 \pm 0.0192912$ (median 0.003000) vs. mean $\pm \mathrm{SD} 0.003639 \pm 0.0048245$ (median 0.001800); $\mathrm{p}=0.052$ ].

Messenger RNA expression levels of patients $(n=38)$ and healthy controls $(n=16)$ with MEFV mutation were compared and the results were not found to be statistically significant [mean \pm SD $0.00765 \pm 0.019291$ (median 0.003000) vs. mean \pm SD $0.00393 \pm 0.004324$ (median 0.00200); $\mathrm{p}=0.191$.

The differences in MEFV mRNA expression were not statistically significant between patients with MEFV M694V homozygous mutations ( $n=3$ ) and those with heterozygous mutations $(n=8)$ $(p=0.221)$. Additionally, significant differences were not detected when we compared the MEFV mRNA expression levels between patients with the E148Q and M694V heterozygous mutations (E148Q ( $\mathrm{n}=8) ;$ M694V ( $\mathrm{n}=8) ;$ E148Q ( $\mathrm{n}=6)$; $\mathrm{p}=0.943)$.

Differences in the MEFV mRNA expression level were not significant between patients with homozygous or heterozygous E148Q mutations $(n=11)$ and patients with homozygous or heterozygote other MEFV mutations $(n=28)$ $(p=0.553)$.

Seventy-one patients diagnosed as having FMF according to the Tel-Hashomer criteria were evaluated, considering 12 clinical symptoms. 
Table 2. Clinical symptoms of Familial Mediterranean fever patients with/without Mediterranean fever gene mutation

\begin{tabular}{|c|c|c|c|c|c|c|c|c|c|}
\hline \multirow[t]{2}{*}{ Clinical symptoms } & \multicolumn{2}{|c|}{ Total patients } & \multicolumn{2}{|c|}{ Mutation positive patients } & \multicolumn{2}{|c|}{ Mutation negative patients } & \multirow[t]{2}{*}{$p$} & \multirow[t]{2}{*}{ OR } & \multirow[t]{2}{*}{$95 \% \mathrm{CI}$} \\
\hline & $\mathrm{n}$ & $\%$ & $\mathrm{n}$ & $\%$ & $\mathrm{n}$ & $\%$ & & & \\
\hline Abdominal pain & 55 & 77.5 & 28 & 73.7 & 27 & 81.8 & $0.413^{*}$ & 0.622 & 0.199-1.949 \\
\hline Fever & 36 & 50.7 & 14 & 36.8 & 22 & 66.7 & $0.012^{*}$ & 0.292 & $0.110-0.776$ \\
\hline Arthralgia & 7 & 9.9 & 3 & 7.9 & 4 & 12.1 & 0.697 & 0.621 & $0.129-3.004$ \\
\hline Erythema & 5 & 7 & 3 & 7.9 & 2 & 6.1 & $1.000^{*}$ & 1.329 & $0.208-8.478$ \\
\hline Sicchasia & 9 & 12.7 & 4 & 10.5 & 5 & 15.2 & $0.724^{*}$ & 0.659 & $0.161-2.690$ \\
\hline Vomitus & 13 & 18.3 & 5 & 13.2 & 8 & 24.2 & $0.228^{*}$ & 0.473 & $0.138-1.624$ \\
\hline Arthritis & 8 & 11.3 & 6 & 15.8 & 2 & 6.1 & $0.270^{\prime}$ & 2.906 & $0.544-15.513$ \\
\hline Chronic arthritis & 0 & 0 & 0 & - & - & - & - & - & - \\
\hline Splenomegaly & 0 & 0 & 0 & - & - & - & - & - & - \\
\hline Hepatomegaly & 0 & 0 & 0 & - & - & - & - & - & - \\
\hline Amyloidosis & 0 & 0 & 0 & - & - & - & - & - & - \\
\hline Proteinuria & 2 & 2.8 & 1 & 2.6 & 1 & 3 & $1.000^{*}$ & 0.865 & $0.052-14.393$ \\
\hline
\end{tabular}

The prevalence of symptoms, from the highest to the lowest, were abdominal pain $(77.5 \%)$, fever $(50.7 \%)$, vomiting (18.3\%), nausea (12.7\%), arthritis (11.3\%), arthralgia (9.9\%), erythema (7\%) and proteinuria (2.8\%). Chronic arthritis, splenomegaly, hepatomegaly and amyloidosis symptoms were not detected in the patients (Table 2).

Patients with MEFV mutation $(n=38)$ and patients with no MEFV mutation (33 patients) were evaluated considering 12 clinical symptoms. The symptom of fever was more frequent in patients who had no MEFV mutation than in patients with MEFV mutation, and the difference was statistically significant $[p=0.0012$, odds ratio $=0.293,95 \% \mathrm{CI}=0.11-0.776]$, (Table 2). Three patients with M694V/M694V genotype had no proteinuria and serum amyloid A protein deposition.

Patients who had MEFV mutation in exon $2(\mathrm{n}=10)$ and patients with MEFV mutation in exon $10 \quad(n=25)$ were evaluated considering 12 clinical symptoms; however, the difference was not statistically significant ( $p>0.05)$, (Table 3 ).

The relationship between some of the MEFV gene mutations found in patients and 12 clinical findings were investigated. However, only

Table 3. Clinical symptoms and genotype correlation in Familial Mediterranean fever patients with Mediterranean fever gene exon 2 and exon 10 mutation

\begin{tabular}{|c|c|c|c|c|c|c|c|}
\hline \multirow[t]{2}{*}{ Clinical symptoms } & \multicolumn{2}{|c|}{$\begin{array}{l}\text { Exon } 2 \text { mutation positive } \\
\text { patients }(n=10)\end{array}$} & \multicolumn{2}{|c|}{$\begin{array}{c}\text { Exon } 10 \text { mutation positive } \\
\text { patients }(\mathrm{n}=25)\end{array}$} & \multirow[t]{2}{*}{$p$} & \multirow[t]{2}{*}{ OR } & \multirow[t]{2}{*}{$95 \% \mathrm{CI}$} \\
\hline & $\mathrm{n}$ & $\%$ & $\mathrm{n}$ & $\%$ & & & \\
\hline Abdominal pain & 7 & 70 & 20 & 80 & $0.661^{\ddagger}$ & 1.714 & $0.323-9.109$ \\
\hline Fever & 4 & 40 & 8 & 32 & 0.706 & 0.706 & $0.155-3.224$ \\
\hline Arthralgia & 2 & 20 & 1 & 4 & 0.190 & 0.167 & $0.013-2.093$ \\
\hline Erythema & 1 & 10 & 1 & 4 & 0.496 & 0.375 & $0.021-6.652$ \\
\hline Sicchasia & 2 & 20 & 1 & 4 & $0.190^{\prime}$ & 0.167 & $0.013-2.093$ \\
\hline Vomitus & 3 & 30 & 1 & 4 & $0.061^{\ddagger}$ & 0.097 & $0.009-1.088$ \\
\hline Arthritis & 0 & 0 & 5 & 20 & 0.292 & 0.667 & $0.518-0.859$ \\
\hline Chronic arthritis & 0 & 0 & 0 & 0 & - & - & - \\
\hline Splenomegaly & 0 & 0 & 0 & 0 & - & - & - \\
\hline Hepatomegaly & 0 & 0 & 0 & 0 & - & - & - \\
\hline Amyloidosis & 0 & 0 & 0 & 0 & - & - & - \\
\hline Proteinuria & 1 & 10 & 0 & 0 & $0.286^{\ddagger}$ & 0.265 & $0.151-0.464$ \\
\hline
\end{tabular}


Table 4. Clinical symptoms and genotype correlation in Familial Mediterranean fever patients with some Mediterranean fever gene mutations

\begin{tabular}{|c|c|c|c|c|c|c|c|c|c|c|c|c|c|c|}
\hline Clinical symptoms & \multicolumn{2}{|c|}{$\begin{array}{c}\text { E148Q } \\
\text { heterozygous } \\
\text { mutations } \\
(\mathrm{n}=8)\end{array}$} & \multicolumn{2}{|c|}{$\begin{array}{c}\text { E148Q } \\
\text { homozygous } \\
\text { mutations } \\
(n=2)\end{array}$} & \multicolumn{2}{|c|}{$\begin{array}{l}\text { M680I (G/C) } \\
\text { heterozygous } \\
\text { mutations } \\
(\mathrm{n}=3)\end{array}$} & \multicolumn{2}{|c|}{$\begin{array}{c}\text { M694V } \\
\text { heterozygous } \\
\text { mutations } \\
(\mathrm{n}=8)\end{array}$} & \multicolumn{2}{|c|}{$\begin{array}{c}\text { M694V } \\
\text { homozygous } \\
\text { mutations } \\
(n=3)\end{array}$} & \multicolumn{2}{|c|}{$\begin{array}{l}\text { V726A } \\
\text { heterozygous } \\
\text { mutations } \\
(n=3)\end{array}$} & \multicolumn{2}{|c|}{$\begin{array}{c}\text { M694V (+) M680I (G/C) } \\
\text { heterozygous } \\
\text { mutations } \\
(\mathrm{n}=3)\end{array}$} \\
\hline Abdominal pain & 6 & 75 & 1 & 100 & 3 & 100 & 5 & 62.5 & 1 & 33.3 & 3 & 100 & 3 & 100 \\
\hline Fever & 3 & 37.5 & 1 & 100 & 2 & 66.6 & 2 & 25 & 2 & 66.6 & 0 & 0 & 1 & 33.3 \\
\hline Arthralgia & 2 & 25 & 0 & 0 & 1 & 33.3 & 0 & 0 & 0 & 0 & 0 & 0 & 0 & 0 \\
\hline Sicchasia & 2 & 25 & 0 & 0 & 0 & 0 & 0 & 0 & 0 & 0 & 0 & 0 & 1 & 33.3 \\
\hline Vomitus & 3 & 37.5 & 1 & 100 & 1 & 33.3 & 0 & 0 & 0 & 0 & 0 & 0 & 0 & 0 \\
\hline Arthritis & 0 & 0 & 0 & 0 & 0 & 0 & 1 & 12.5 & 2 & 66.6 & 0 & 0 & 1 & 33.3 \\
\hline Chronic arthritis & 0 & 0 & 0 & 0 & 0 & 0 & 0 & 0 & 0 & 0 & 0 & 0 & 0 & 0 \\
\hline Splenomegaly & 0 & 0 & 0 & 0 & 0 & 0 & 0 & 0 & 0 & 0 & 0 & 0 & 0 & 0 \\
\hline Hepatomegaly & 0 & 0 & 0 & 0 & 0 & 0 & 0 & 0 & 0 & 0 & 0 & 0 & 0 & 0 \\
\hline Amyloidosis & 0 & 0 & 0 & 0 & 0 & 0 & 0 & 0 & 0 & 0 & 0 & 0 & 0 & 0 \\
\hline Proteinuria & 1 & 12.5 & 0 & 0 & 0 & 0 & 0 & 0 & 0 & 0 & 0 & 0 & 0 & 0 \\
\hline
\end{tabular}

frequency calculation could be made since the number of the patient group was low (Table 4).

\section{DISCUSSION}

We investigated the distribution of MEFV gene mutations and mRNA expression levels in patients previously diagnosed with FMF and healthy controls living in Turkey's Trakya Area.

According to previous studies investigating the frequency of MEFV gene mutations in different geographic regions of Turkey (specifically, the Aegean, Central Anatolia, Black Sea, and South Eastern Anatolia regions), the most frequent mutation is the M694V mutation. ${ }^{11-16}$ In our study group, the most frequent MEFV mutation was also M694V, and based on this result, we suggested that the distribution of MEFV gene mutations does not differ greatly between the different geographic areas of Turkey.

It has been reported that the approximate prevalence of FMF is $1 / 1000$, and the rate of carriers (heterozygotes) is $1 / 5$ in Turkey. 8,9 According to results of our study, the rate of the carriers (heterozygotes) is $21.9 \%$, and this result confirms that the rate of carriers heterozygous for MEFV mutations is high in the Turkish population.

Öztürk et al. ${ }^{16}$ analyzed 452 pediatric FMF patients with a mean age of $12.4 \pm 4.7$ (range, 2-30 years) and indicated that the common clinical findings were abdominal pain (86.3\%), fever (81.9\%), myalgia (58.8\%) and arthritis/ arthralgia (49\%). Six (2.9\%) and nine (4.3\%) of 207 patients carrying two mutant alleles had amyloidosis and proteinuria respectively.

Yigit et al. ${ }^{14}$ (Black Sea region/Turkey), Paşa et al. $^{13}$ (Southeastern region/Turkey) and Solak et al. ${ }^{4}$ (Aegean region/Turkey) reported that amyloidosis was more frequent in adult patients with the M694V/M694V genotype. Gürkan et al. ${ }^{5}$ (Trakya region/Turkey) also detected no amyloidosis in two adult patients with the M694V/ M694V genotype.

In the present study, abdominal pain and fever were the most frequent symptoms. Since fever was more frequent in patients with no MEFV mutation than in patients carrying the MEFV mutation $(p=0.012)$, it can be concluded that diagnosing FMF only with fever-episodes could be deceptive. Amyloidosis and proteinuria were not detected in three patients who had M694V/ M694V genotype; this may have resulted from early diagnosis and colchicine treatment.

Phenotype and genotype associations were evaluated and no statistically significant relation was found. We suggest that the small number of patients $(n=71)$ and tender age $(10.7 \pm 4.4)$ (this may cause the patients to express symptoms of the disease incorrectly and have mix symptoms), and also early diagnosis and colchicine treatment may prevent amyloidosis.

Kireçtepe et al., ${ }^{2}$ Üstek et al., ${ }^{3}$ and Notarnicola et al. ${ }^{1}$ investigated the MEFV mRNA expression levels of FMF patients and found that in those 
with MEFV mutations, MEFV mRNA expression levels are significantly low. We have also confirmed that the MEFV mRNA expression levels of patients are significantly lower than that of the controls.

Kireçtepe et al. ${ }^{2}$ (pediatric patients) and Üstek et al. $^{3}$ compared the MEFV mRNA expression levels between FMF patients with MEFV mutations and those without mutations, and they could not detect any significant relationship. However, we found that there was a borderline statistically significant difference between FMF patients with and those without MEFV mutations. This result partly supports the hypothesis of Notarnicola et al. ${ }^{1}$ "Inside the possible mechanisms explaining the differences observed between the study groups, MEFV mRNA stability ranging with the presence of MEFV gene mutations".

According to the study of Notarnicola et al., ${ }^{1}$ the MEFV mRNA expression level differences between healthy controls and healthy carriers were statistically significant $(p=0.008)$, and they suggested that decreasing MEFV mRNA expression levels may lead to molecular failure, which is independent of FMF symptoms. We did not find significant differences in MEFV mRNA expression between healthy controls and healthy carriers. Notarnicola et al. ${ }^{1}$ reported that decreased MEFV mRNA expression in monocytes is more significant than decreased MEFV mRNA expression in polymorphonuclear cells. However, in our study, we investigated the MEFV mRNA expression level only in polymorphonuclear cells. Hence, we suggest that this can explain the differences between the two studies.

Notarnicola et al. ${ }^{1}$ reported that the MEFV mRNA expression level is related to the MEFV genotype and the FMF phenotype. M694V mutants have the lowest MEFV mRNA expression levels, while E148Q mutants have the highest MEFV mRNA expression levels. In our study, we compared the MEFV mRNA expression levels between patients homozygous for the M694V mutation $(\mathrm{n}=3)$ and patients heterozygous for the M694V mutation ( $\mathrm{n}=8)$. We also compared patients and controls heterozygous for the E148Q and M694V mutations (E148Q ( $\mathrm{n}=8), \mathrm{M} 694 \mathrm{~V}$ $(\mathrm{n}=8)$, E148Q $(\mathrm{n}=6)$. Unfortunately, we could not detect a relationship between the genotype and the phenotype, unlike in the study of Notarnicola et al. ${ }^{1}$ We suggest that this difference is because the number of patients and controls with E148Q and M694V mutations was so small.

In conclusion, this work is only the second study to investigate the relationship between MEFV mutations and the MEFV mRNA expression levels in pediatric FMF patients living in Turkey's Trakya region. Our study is different from the study of Kireçtepe et al. $^{2}$ because we used a higher number of patients $(n=51)$ and controls $(n=21)$ and the number of MEFV gene mutations investigated ( $\mathrm{n}=5$ mutation). Our study supports the findings of Kireçtepe et al., ${ }^{2}$ which revealed that the MEFV mRNA expression levels of infant FMF patients is lower than the MEFV mRNA expression levels of healthy controls.

\section{Acknowledgements}

We would like to thank Selin Tan (Trakya University, Department of Medical Genetics) and Gülce Sar1 (Yeditepe University, Department of Molecular Medicine) for their contributions.

\section{Declaration of conflicting interests}

The authors declared no conflicts of interest with respect to the authorship and/or publication of this article.

\section{Funding}

This study is supported by Trakya University Scientific Research Projects Unit (TUBAP 2009-129)

\section{REFERENCES}

1. Notarnicola C, Didelot MN, Koné-Paut I, Seguret F, Demaille J, Touitou I. Reduced MEFV messenger RNA expression in patients with familial Mediterranean fever. Arthritis Rheum 2002;46:2785-93.

2. Kirectepe AK, Kasapcopur O, Arisoy N, Celikyapi Erdem G, Hatemi G, Ozdogan H, et al. Analysis of MEFV exon methylation and expression patterns in familial Mediterranean fever. BMC Med Genet 2011;12:105.

3. Ustek D, Ekmekci CG, Selçukbiricik F, Cakiris A, Oku B, Vural B, et al. Association between reduced levels of MEFV messenger RNA in peripheral blood leukocytes and acute inflammation. Arthritis Rheum 2007;56:345-50.

4. Solak M, Yıldız H, Koken R, Erdoğan MO, Eser B, Sen TA, et al. Ailevi Akdeniz Ateşi ön tanısı alan 165 olgunun MEFV geni mutasyonlarının incelenmesi. Turkiye Klinikleri J Med Sci 2008;28:117-22. 
5. Gürkan H, Ozkayın EN, Tabakçıŏlu K, Algüneş Ç. Trakya populasyonundaki Ailevi Akdeniz Ateşi hastalarında MEFV geni ekson 2 ve ekson 10 gen bölgesi mutasyonları. Trakya Univ Tip Fak Derg 2010;271:37-43.

6. Öztürk A, Özçakır B, Ekim M, Akar N. Is MEFV Gene Arg202Gln (605 G>A) A disease-causing mutation? Turk J Med Sci 2008;38:205-8.

7. Giaglis S, Papadopoulos V, Kambas K, Doumas M, Tsironidou V, Rafail S, et al. MEFV alterations and population genetics analysis in a large cohort of Greek patients with familial Mediterranean fever. Clin Genet 2007;71:458-67.

8. Touitou I. The spectrum of Familial Mediterranean Fever (FMF) mutations. Eur J Hum Genet 2001;9:473-83.

9. Ozen S, Karaaslan Y, Ozdemir O, Saatci U, Bakkaloglu A, Koroglu E, et al. Prevalence of juvenile chronic arthritis and familial Mediterranean fever in Turkey: a field study. J Rheumatol 1998;25:2445-9.

10. Available from: http://fmf.igh.cnrs.fr/ISSAID/infevers

11. Akin H, Onay H, Turker E, Cogulu O, Ozkinay F. MEFV mutations in patients with Familial Mediterranean Fever from the Aegean region of Turkey. Mol Biol Rep 2010;37:93-8.
12. Gunel-Ozcan A, Sayin DB, Misirlioğlu ED, Güliter $\mathrm{S}$, Yakaryilmaz F, Ensari C. The spectrum of FMF mutations and genotypes in the referrals to molecular genetic laboratory at Kirikkale University in Turkey. Mol Biol Rep 2009;36:757-60.

13. Pasa S, Altintas A, Devecioglu B, Cil T, Danis $\mathrm{R}$, Isi $\mathrm{H}$, et al. Familial Mediterranean fever gene mutations in the Southeastern region of Turkey and their phenotypical features. Amyloid 2008;15:49-53.

14. Yigit S, Bagci H, Ozkaya O, Ozdamar K, Cengiz K, Akpolat T. MEFV mutations in patients with familial Mediterranean fever in the Black Sea region of Turkey: Samsun experience [corrected]. J Rheumatol 2008;35:106-13.

15. Demirkaya E, Tunca Y, Gok F, Ozen S, Gul D. A very frequent mutation and remarkable association of $\mathrm{R} 761 \mathrm{H}$ with $\mathrm{M} 694 \mathrm{~V}$ mutations in Turkish familial Mediterranean fever patients. Clin Rheumatol 2008;27:729-32.

16. Ozturk C, Halicioglu O, Coker I, Gulez N, Sutçuoglu $\mathrm{S}$, Karaca N, et al. Association of clinical and genetical features in FMF with focus on MEFV strip assay sensitivity in 452 children from western Anatolia, Turkey. Clin Rheumatol 2012;31:493-501. 